\title{
Exercise, Science and Designer Doping: Traditional and Emerging Trends
} Graham MR', Davies B ${ }^{2}$, Grace $\mathrm{FM}^{3}$, Evans $\mathrm{PJ}^{4}$ and Baker $\mathrm{JS}^{3}$

${ }^{1}$ Sport and Exercise Science, Institute of Health, Medical Science and Society Science, Glyndwr University, Wrexham, Wales, UK, LL11 2AW

${ }^{2}$ Health and Exercise Science, University of Glamorgan, Pontypridd, Wales, UK, CF83 1DL

${ }^{3}$ Exercise Science, University of the West of Scotland, Hamilton, Scotland, ML3 OJB

${ }^{4}$ Department of Endocrinology, Royal Gwent Hospital, Newport, Wales, UK, NP20 2UB

\begin{abstract}
The list of doping agents is enormous, and for the majority, any beneficial sporting effect is contentious. The World Anti-Doping Agency (WADA) and United Kingdom (UK) Anti-Doping have difficulty detecting the peptide hormones, growth hormone (GH), insulin-like growth factor-1 (IGF-I), insulin and erythropoietin (Epo), because they require blood analysis. Only in the last two years has an athlete been convicted of taking $\mathrm{GH}$, which is still being used as a doping agent because the window for detection is so brief. This positive test was not contested, which suggests that science may be winning the war on drugs. Athletes appear to have ceased taking insulin, because of its life-threatening acute effects, and in recent years no adverse analytical findings have been reported for this drug.
\end{abstract}

"Older" doping agents, which are known to enhance performance in sport, include testosterone and their derivatives, anabolic steroids.

The pharmaceutical industry continues to manufacture new medicines, pushing back the boundaries in combating wasting disease states and the ageing process, but is inadvertently producing the latest generation of doping agents. This will challenge anti-doping scientists.

WADA's banned list also includes fibroblast growth factors, hepatocyte growth factor, mechano growth factors, platelet-derived growth factor, vascular-endothelial growth factor which may promote muscle, tendon or ligament development, vascularisation, energy utilisation, regenerative capacity and fibre type. Athletes will use whatever they believe works, but can only use what is available. Internet companies offer these anabolic products, but their veracity cannot be proven.

There are questions that need to be answered? Are these products available to athletes, do they enhance performance, are athletes really taking them and are they so difficult to detect. The internet has made them available to anyone with a credit card and it appears that if they are cycled correctly, unless an athlete is caught in possession of them, the opportunity of proving a case of doping is almost impossible.

Keywords: Anabolic steroids; Epo; GH; IGF-I; Insulin; Mechano growth factor; Myostatin

\section{Introduction}

The involvement of sport's scientists in elite sport has led them to develop improved nutrition, physiological and psychological techniques but also to be significantly implicated in the development and use of performance enhancing drugs [1]. East German scientists were involved in the state-sponsored systematic doping of athletes in the former East Germany [2]. American scientists have also been concerned in the dissemination of performance and image enhancing drugs used in international sport. Dr John Ziegler, originally developed the androgenic anabolic steroid (AAS) Methandrostenolone (Dianabol) which was released in the USA in 1958 by the pharmaceutical giant, Ciba. Ziegler pioneered its athletic use as an aid to muscle growth by bodybuilders, administering it to USA weightlifting champion Bill March in 1959 when he was the physician to the USA Weightlifting team [3]. This appears to be the first documented use of AAS in sport [4]. The emphasis and rewards placed on winning and breaking world records has made this liaison between sporting performance and science almost inextricable.

In 1960, Danish cyclist, Knut Jensen, was the first athlete to die in Olympic competition due to doping, during the $100 \mathrm{~km}$ team time trial race. His autopsy revealed traces of amphetamine [5]. British cyclist Tom Simpson, whose motto was "if it takes ten to kill you, take nine and win....." was the first death caused by doping in the Tour de France, in 1967. Two tubes of amphetamines and a further empty tube were found in the rear pocket of his racing jersey. His autopsy revealed traces of amphetamine, alcohol and the diuretic frusemide.

In 1967 to combat doping, the International Olympic Commitee (IOC) established a Medical Commission which provided three fundamental principles: protection of the health of athletes, respect for medical and sport ethics, and equality for all competing athletes [6].

At that time the list of banned substances included narcotic analgesics, stimulants and alcohol. Although it was suspected that AAS were being used at this time, testing methods were insufficiently developed to warrant their inclusion. The first compulsory doping controls were at the Winter Olympic Games in Grenoble, France in 1968 [7].

In the 1984 Olympics, some team doctors were involved in exploiting

*Corresponding author: Graham MR, Sport and Exercise Science, Institute of Health, Medical Science and Society Science, Glyndwr University, Wrexham Wales, UK, LL112AW, E-mail: drgraham.ac.uk@live.co.uk

Received September 11, 2011; Accepted October 25, 2011; Published Octobe 28, 2011

Citation: Graham MR, Davies B, Grace FM, Evans PJ, Baker JS (2011) Exercise Science and Designer Doping: Traditional and Emerging Trends. J Steroids Hormon Sci 2:109. doi:10.4172/2157-7536.1000109

Copyright: (c) 2011 Graham MR, et al. This is an open-access article distributed under the terms of the Creative Commons Attribution License, which permits unrestricted use, distribution, and reproduction in any medium, provided the original author and source are credited. 
the doping regulations. Team doctors had to fill in declarations for all athletes using specific drugs perceived to be performance enhancing. If competitors produced a doctor's certificate stating that they needed a drug for health reasons, they would not be disqualified, if drug checks proved positive. Following a large number of positive urinalyses some teams provided medical certificates covering the whole team [8]. This identified the deception that physicians were prepared to be concerned in to win at any cost. One of the drugs in this instance was a betablocker, which could in fact impede performance, in endurance events.

Convictions of celebrity athletes for doping offences and their subsequent confessions has identified the extent of their subterfuge [914].

The authorities are partly to blame. Zero tolerance and a lifetime ban for any offence, would be a far greater deterrent than a two year ban, for the first adverse analytical finding (AAF), a two year to lifetime ban for second or subsequent violations and a four year to lifetime ban for trafficking. The World Anti-Doping Agency (WADA) have written extensive documents, euphemising the fact that they are prepared to offer "deals" with offending dopers in an attempt to identify the provenance of these doping agents and suppliers [15].

When rewards for athletic success are so great, human nature is such that certain individuals will always succumb to fruit of the forbidden tree. Athletes are more concerned with failure than they are about adverse health effects as a consequence of cheating [16]

Doping could be halted overnight if the sanctions were severe enough.

Specific questions need to be answered. Do these agents really enhance performance? Are they harmful? Are they detectable? This short review will assess current doping agents being used, whether they have the desired effect, and whether athletes can beat "the test".

\section{Anabolic Steroids}

Androgenic anabolic steroids (AAS) are a group of synthetic compounds similar in chemical structure to the natural anabolic steroid testosterone (see Figure 1) [17]. In 1969, the first application of radioimmunoassay (RIA) for the measurement of steroids in biological fluids was published [18].

The IOC Medical Commission acted by the introduction of AAS as a banned class in 1974 following the development of a screen for the $17 \alpha$-alkylated orally active drugs, in the biological medium of urine. Any presumptive positive samples could then be analysed by gas chromatography-mass spectrometry (GC-MS) for confirmatory identification [19]. The advantages that GC/MS screen provided, resulted in the replacement of RIA, which is today's accepted method.

AAS detection has always been problematic. They are abused by athletes during training and are not taken during the actual competitive period, in an attempt to avoid detection. Since oral preparations are cleared from the body between 2-14 days following withdrawal, and water soluble "injectables" after 4 weeks, it is possible to use these agents during periods of intensive training and test negative. In 1982, the IOC test for detection of testosterone administration was based on the GC/MS determination of the urinary ratio of testosterone (T) to its $17 \alpha$-epimer, epitestosterone (E), following glucuronide hydrolysis, commonly referred to as $\mathrm{T} / \mathrm{E}$ ratio [20]. In healthy men and women, the $\mathrm{T} / \mathrm{E}$ ratio is approximately 1 . Supraphysiological doses of testosterone cause an increase in the ratio as a result of increased excretion of testosterone. The T/E ratio may be augmented as a consequence of dose-dependent inhibition of testicular steroidogenesis. When supraphysiological doses of testosterone are taken, suppression of luteinising hormone secretion decreases urinary epitestosterone glucuronide. The WADA Medical Code stipulates that if a ratio of $\mathrm{T} / \mathrm{E}$ is greater than 4 , it is mandatory that the relevant medical authority conducts an investigation before the sample is declared positive. Investigations include a review of $\mathrm{T} / \mathrm{E}$ results from previous tests, subsequent tests and also results of any serum endocrine investigations. The athlete will then be monitored at least monthly for three months. However, an athlete may have a physiological increased ratio being a natural biological outlier [21]. In the case of a $\mathrm{T} / \mathrm{E}$ ratio $\geq 4$, isotope ratio mass spectrometry (IRMS) can determine the exogenous administration [22].

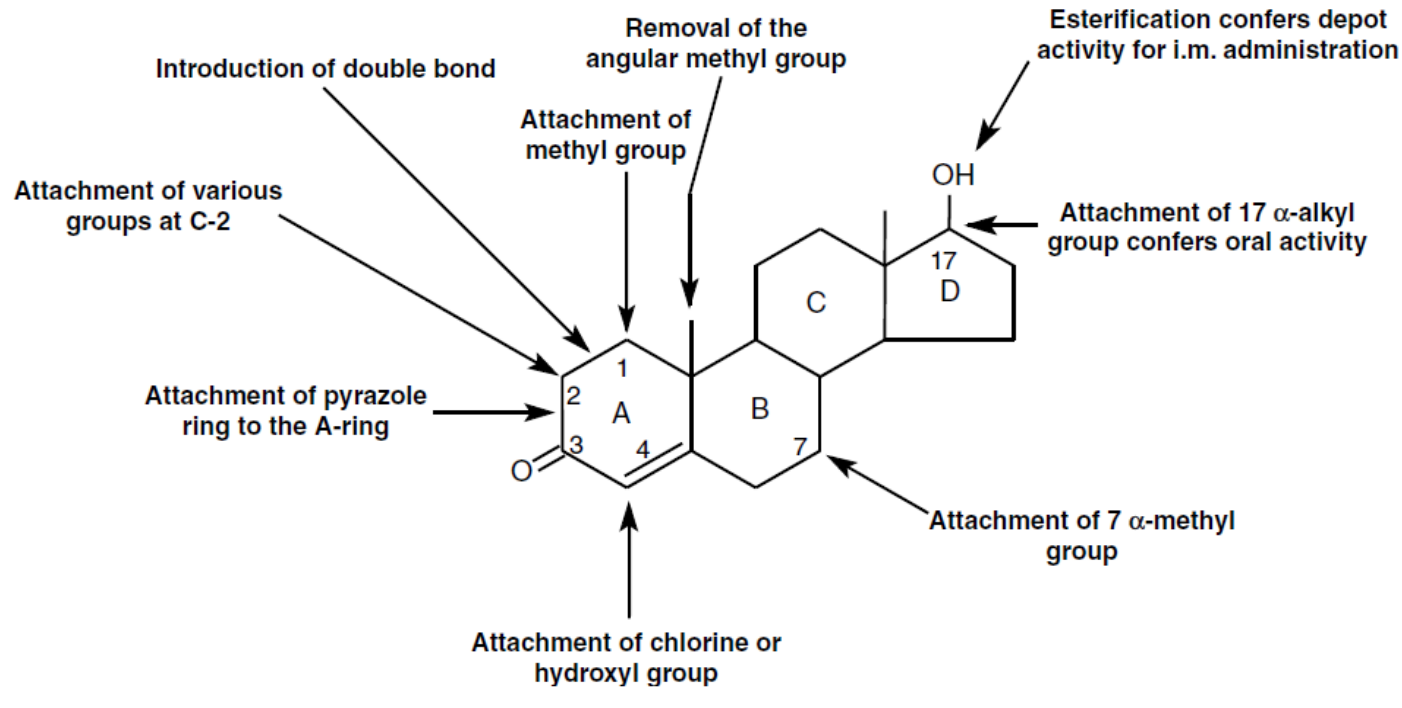

$\mathrm{IM}=$ intramuscular

Figure 1: The structure of testosterone and structural modifications to the A- and B-rings of this steroid molecule that increase anabolic activity. Substitution at C-17 confers oral or depot activity (Reproduced with permission from Kicman and Gower, 2003). 
Citation: Graham MR, Davies B, Grace FM, Evans PJ, Baker JS (2011) Exercise, Science and Designer Doping: Traditional and Emerging Trends. J Steroids Hormon Sci 2:109. doi:10.4172/2157-7536.1000109

\section{Do AAS enhance performance?}

AAS were proven only as recently as 1996 to increase muscle mass and strength in adult males [23]. Extrapolation of these effects to the sporting arena is not in doubt and is the reason why they are still the most common AAS in anti-dope testing today [24].

The prevalence of AAS use, the risks to an athlete's health and the methods used to detect them by urinalysis are well documented in the literature [25].

\section{Accessibility}

The price of genuine AAS and their restriction due to their classification under the misuse of drugs act, 1971, has initiated an enormous counterfeit market. The most popular AAS are presented in $10 \mathrm{ml}$ multi-dose vials, claiming to have very high concentrations of active ingredients. Multiple websites offer AAS, at varying prices [26]. A large majority of these counterfeit products are made in unlicensed laboratories in countries where the law is more permissive than the UK or USA, such as Mexico, China and Thailand. The dangers associated with such products are patently obvious. Table 1 identifies genuine prescription medicines, which are AAS and have been used as doping agents and the cost to the National Health Service in the UK. Table 2 identifies potential counterfeit AAS that are currently used by bodybuilders, weightlifters, powerlifters and rugby players, available from other sources, including internet companies.

\section{Growth Hormone (GH)}

The somatotroph cells in the anterior pituitary synthesise and secrete the polypeptide human growth hormone (hGH) which appears to have been isolated in 1944 [27] and then manufactured by recombinant DNA technology in the mid 1980's producing recombinant human growth hormone (rhGH) [28]. It is secreted as a 191-amino-acid 4-helix bundle protein, weighing 22,000 daltons (70-80\%) and a less abundant 176-amino-acid form, weighing 20,000 daltons (20-30\%) [29]. See Figure 2 for GH three-dimensional configuration.

Athletes have been trying to extrapolate postulated benefits to achieve physical improvement since 1982 [30]. Its powerful effects in GH deficiency (GHD) were proven in 1989 [31] and these effects were also experienced in elderly men aged 60 years of age in 1990 [32]

Its seizure of $\mathrm{rhGH}$ in the possession of Chinese swimmers at the 1998 World Swimming Championships and again discovery of possession by cyclists at the Tour de France cycling event in 1998 have proven its abuse at an elite level [33].

\section{Does rhGH enhance performance?}

Extensive research with rhGH on non-competitive athletes has produced controversial results. Contemporary evidence appears to contradict the proven anabolic effect of rhGH in deficiency, in drug naïve healthy human muscle, in males (mean age of 28 years) [33]. Nor

\begin{tabular}{|c|c|c|c|}
\hline Product & $\begin{array}{l}\text { Pharmaceutical } \\
\text { Manufacturer }\end{array}$ & Manufacturers Price & Mode of delivery \\
\hline $\begin{array}{l}\text { Sustanon } 250 \AA \\
\text { (testosterone propionate } 30 \mathrm{mg} \text {, testosterone phenylpropionate } 60 \mathrm{mg} \text {, } \\
\text { testosterone isocaproate } 60 \mathrm{mg} \text {, and testosterone decanoate } 100 \mathrm{mg} \text { ) } \\
250 \mathrm{mg} / 1 \mathrm{ml}\end{array}$ & Organon & $\begin{array}{l}\text { net price } \\
1-\mathrm{mL} \text { amp }=£ 2.45\end{array}$ & Intramuscular \\
\hline $\begin{array}{l}\text { Testosterone enantate } \\
250 \mathrm{mg} / 1 \mathrm{ml}\end{array}$ & $\begin{array}{l}\text { Non-Proprietary } \\
\text { (Generic) }\end{array}$ & $\begin{array}{l}\text { net price } \\
1-\mathrm{mL} \text { amp }=£ 13.33\end{array}$ & Intramuscular \\
\hline $\begin{array}{l}\text { Deca-Durabolin }{ }^{\circledR} \\
\text { (nandrolone decanoate) } \\
50 \mathrm{mg} / 1 \mathrm{ml}\end{array}$ & Organon & $\begin{array}{l}\text { net price } \\
1-\mathrm{mL} \text { amp }=£ 3.17\end{array}$ & Intramuscular \\
\hline $\begin{array}{l}\text { Testosterone propionate (Virormone } ® \text { ) } \\
50 \mathrm{mg} / 1 \mathrm{ml}\end{array}$ & Nordic & $\begin{array}{l}\text { net price } \\
\text { 2-mL } \text { amp }=£ 4.50\end{array}$ & Intramuscular \\
\hline $\begin{array}{l}\text { Testosterone undecanoate (Nebido) } \\
250 \mathrm{mg} / 1 \mathrm{ml}\end{array}$ & Bayer Schering & $\begin{array}{l}\text { net price } \\
\text { 4-mL amp }=£ 76.70\end{array}$ & Intramuscular \\
\hline $\begin{array}{l}\text { Restandol@ Testocaps } \\
\text { (testosterone undecanoate) } \\
40 \text { mg/capsule }\end{array}$ & Organon & $\begin{array}{l}\text { net price } \\
30 \text {-cap pack }=£ 8.55 \\
60 \text {-cap pack }=£ 17.10\end{array}$ & Oral \\
\hline $\begin{array}{l}\text { Pro-Viron }{ }^{\circledR} \\
\text { (mesterolone) } \\
25 \mathrm{mg} / \text { tablet }\end{array}$ & Bayer Schering & $\begin{array}{l}\text { Net price } \\
30 \text {-tab pack }=£ 4.19\end{array}$ & Oral \\
\hline $\begin{array}{l}\text { Striant } \circledast \mathrm{SR} \\
\text { (testosterone tablet) } \\
30 \mathrm{mg} / \text { tablet }\end{array}$ & (The Urology Co. ) & $\begin{array}{l}\text { net price } \\
60 \text {-tab pack }=£ 45.84\end{array}$ & $\begin{array}{l}\text { Mucoadhesive buccal tablets / } \\
\text { Sublingual }\end{array}$ \\
\hline $\begin{array}{l}\text { Intrinsa }{ }^{\circledR} \\
\text { (Testosterone patch) } \\
\text { (self-adhesive, releasing testosterone } 300 \text { mcg/24 hours) }\end{array}$ & Warner Chilcott & $\begin{array}{l}\text { net price } \\
\text { 8-patch pack } \\
=£ 26.91\end{array}$ & Transdermal \\
\hline $\begin{array}{l}\text { Testim }{ }^{\circledR} \\
\text { (Testosterone gel } \\
50 \mathrm{mg} / 5 \mathrm{gm})\end{array}$ & Ferring & $\begin{array}{l}\text { net price } \\
\text { (testosterone } 50 \mathrm{mg} / 5 \mathrm{~g} \\
\text { tube) } \\
30 \text {-tube pack }=£ 32.00\end{array}$ & Transdermal \\
\hline $\begin{array}{l}\text { Testogel }{ }^{\circledR} \\
\text { (Testosterone gel) } \\
50 \mathrm{mg} / 5 \mathrm{gm} \text { sachet }\end{array}$ & Bayer Schering & $\begin{array}{l}\text { net price } \\
30 \text {-sachet pack } \\
=£ 31.11\end{array}$ & Transdermal \\
\hline $\begin{array}{l}\text { Tostran® } \\
\text { (testosterone gel } 2 \%) \\
\text { (10 mg/metered application) }\end{array}$ & ProStrakan & $\begin{array}{l}\text { net price } \\
60 \text {-gm multidose dispenser } \\
=£ 26.67\end{array}$ & Transdermal \\
\hline $\begin{array}{l}\text { Testosterone } \\
100 \mathrm{mg}\end{array}$ & Organon & $\begin{array}{l}\text { net price } \\
100 \mathrm{mg}=£ 7.40 ; \\
200 \mathrm{mg}=£ 13.79\end{array}$ & Implant \\
\hline
\end{tabular}

Table 1: Prescription only Medicines, Testosterone and Esters used in hormone replacement 
Citation: Graham MR, Davies B, Grace FM, Evans PJ, Baker JS (2011) Exercise, Science and Designer Doping: Traditional and Emerging Trends. J Steroids Hormon Sci 2:109. doi:10.4172/2157-7536.1000109

\begin{tabular}{|c|c|c|c|}
\hline Product & $\begin{array}{l}\text { Black-market } \\
\text { Pharmaceutical Manufacturer }\end{array}$ & $\begin{array}{l}\text { Black-market } \\
\text { Wholesale Price }\end{array}$ & $\begin{array}{l}\text { Black-market } \\
\text { Retail Price }\end{array}$ \\
\hline \multicolumn{4}{|l|}{ Anabolic Steroid Hormones (IM) } \\
\hline $\begin{array}{l}\text { Sustanon } \\
250 \mathrm{mg}(1 \mathrm{ml})\end{array}$ & Generic (non-proprietary)/ Organon (Pakistan) & $£ 1.75$ & $£ 2.5$ \\
\hline $\begin{array}{l}\text { Testosterone enanthate } \\
250 \mathrm{mg}(1 \mathrm{ml})\end{array}$ & $\begin{array}{l}\text { Generic (non-proprietary)/ Apex/Prochem/Dragon/British } \\
\text { Dragon, Pharmaceuticals }\end{array}$ & $£ 2$ & $£ 3.5$ \\
\hline $\begin{array}{l}\text { Testosterone } 400 \\
\text { (testosterone propionate, cypionate and enanthate) } \\
(10 \mathrm{mls})\end{array}$ & $\begin{array}{l}\text { Generic (non-proprietary)/ Apex/Prochem/Dragon/British } \\
\text { Dragon, Pharmaceuticals }\end{array}$ & $£ 18$ & $£ 30$ \\
\hline $\begin{array}{l}\text { Nandrolone } 300 \mathrm{mg} / \mathrm{ml} \\
(10 \mathrm{mls})\end{array}$ & $\begin{array}{l}\text { Generic (non-proprietary)/ Apex/Prochem/Dragon/British } \\
\text { Dragon, Pharmaceuticals }\end{array}$ & $£ 19$ & $£ 30$ \\
\hline $\begin{array}{l}\text { Masteron (Drostanolone Propionate) } \\
100 \mathrm{mg} / \mathrm{ml}(10 \mathrm{mls})\end{array}$ & $\begin{array}{l}\text { Generic (non-proprietary)/ Apex/Prochem/Dragon/British } \\
\text { Dragon, Pharmaceuticals }\end{array}$ & $£ 20$ & $£ 30$ \\
\hline $\begin{array}{l}\text { Virormone (Testosterone propionate) }(100-125 \mathrm{mg} / \mathrm{ml}) \\
(10 \mathrm{mls})\end{array}$ & $\begin{array}{l}\text { Generic (non-proprietary)/ Apex/Prochem/Dragon/British } \\
\text { Dragon, Pharmaceuticals }\end{array}$ & $£ 14$ & $£ 20$ \\
\hline $\begin{array}{l}\text { Testosterone cypionate } 100 \mathrm{mg} / \mathrm{ml} \\
(10 \mathrm{mls})\end{array}$ & $\begin{array}{l}\text { Generic (non-proprietary)/ Apex/Prochem/Dragon/British } \\
\text { Dragon, Pharmaceuticals }\end{array}$ & $£ 17$ & $£ 25$ \\
\hline $\begin{array}{l}\text { Trenbolone acetate; } \\
\text { Trenbolone enanthate } \\
(150 \mathrm{mg} / \mathrm{ml}) \\
(10 \mathrm{mls})\end{array}$ & $\begin{array}{l}\text { Generic (non-proprietary)/ Apex/Prochem/Dragon/British } \\
\text { Dragon, Pharmaceuticals }\end{array}$ & $£ 20$ & $£ 30$ \\
\hline $\begin{array}{l}\text { Parabolon (trenbolone hexahydrobenzylcarbonate) } \\
(75-150 \mathrm{mg} / \mathrm{ml}) \\
(10 \mathrm{mls})\end{array}$ & Negma & & \\
\hline $\begin{array}{l}\text { Equitest } 400 \text { (testosterone undecanoate } 240 \mathrm{mg} \text {, boldenone } \\
\text { undecanoate } 160 \mathrm{mg} / \mathrm{ml}) \\
(10 \mathrm{mls})\end{array}$ & Prochem & $£ 20$ & $£ 30$ \\
\hline $\begin{array}{l}\text { Super-tren } 2000 \\
\text { (methyltrienolone } 2000 \mathrm{mcg} / \mathrm{ml}) \\
(10 \mathrm{mls})\end{array}$ & Prochem & $£ 27$ & $£ 50$ \\
\hline \multicolumn{4}{|l|}{ Anabolic Steroid Hormones (Oral) } \\
\hline $\begin{array}{l}\text { Primobol } 50 \\
\text { (Methenolone tablets) } \\
50 \mathrm{mg} / \text { tablet } \\
30 \text { tabs }\end{array}$ & British Dragon Pharmaceuticals & $£ 38$ & $£ 50$ \\
\hline $\begin{array}{l}\text { Anavar/Oxanobol (oxandrolone) } \\
10-50 \text { mg/tablet } \\
60 \text { tabs }\end{array}$ & $\begin{array}{l}\text { Generic (non-proprietary)/ Apex/Prochem/Dragon/British } \\
\text { Dragon, Pharmaceuticals }\end{array}$ & $£ 38$ & $£ 50$ \\
\hline $\begin{array}{l}\text { Winstrol } \\
\text { (stanozolol) } \\
10-50 \mathrm{mg} / \text { tablet } 50 \text { tabs }\end{array}$ & $\begin{array}{l}\text { Generic (non-proprietary)/ Apex/Prochem/Dragon/British } \\
\text { Dragon, Pharmaceuticals }\end{array}$ & $£ 28$ & $£ 35$ \\
\hline $\begin{array}{l}\text { Androlic/Anadrol/Oxydrol (Oxymetholone tablets) } \\
50 \mathrm{mg} / \text { tablet } \\
60 \text { tablets }\end{array}$ & $\begin{array}{l}\text { Generic (non-proprietary)/ Apex/Prochem/Dragon/British } \\
\text { Dragon, Pharmaceuticals }\end{array}$ & $£ 28$ & $£ 60$ \\
\hline $\begin{array}{l}\text { Dianabol/Methanobol/DBol (Methandienone/ } \\
\text { Methandrostenolone) 10mg/tablet } \\
\text { (500 tablets) }\end{array}$ & $\begin{array}{l}\text { Generic (non-proprietary)/ Apex/Prochem/Dragon/British } \\
\text { Dragon, Pharmaceuticals }\end{array}$ & $£ 40$ & $£ 55$ \\
\hline \multicolumn{4}{|l|}{ Peptide Hormones } \\
\hline $\begin{array}{l}\text { Hygetropin } \\
(\text { rhGH) } \\
100 \mathrm{IU}\end{array}$ & Hygene Biopharm Co.,Ltd. & $£ 100$ & $£ 140$ \\
\hline $\begin{array}{l}\text { GenLei® Jintropin }{ }^{\mathrm{TM}} \\
(\mathrm{rhGH}) \\
100 \mathrm{IU}\end{array}$ & Gene Science Pharmaceutical Co., Ltd. & $£ 100$ & $£ 140$ \\
\hline $\begin{array}{l}\text { Turbovital } \\
\text { (rhlgf-1) } \\
1000 \mathrm{mcg} \\
\end{array}$ & Hygene Biopharm Co.,Ltd. & $£ 200$ & $£ 285$ \\
\hline \multicolumn{4}{|l|}{ Growth Hormone Secretagogues } \\
\hline $\begin{array}{l}\text { Hexarelin/Sermorelin/lpamorelin } \\
\text { (growth hormone releasing hormone) } \\
\text { 2mg/amp }\end{array}$ & ProPeptides Co., Ltd & $£ 24$ & $£ 50$ \\
\hline \multicolumn{4}{|l|}{ Myostatin inhibitor } \\
\hline $\begin{array}{l}\text { Follistatin } 344 \\
(5 \mathrm{mcg})\end{array}$ & Southern Research Co., Ltd & $£ 62$ & $£ 100$ \\
\hline
\end{tabular}

Table 2: 


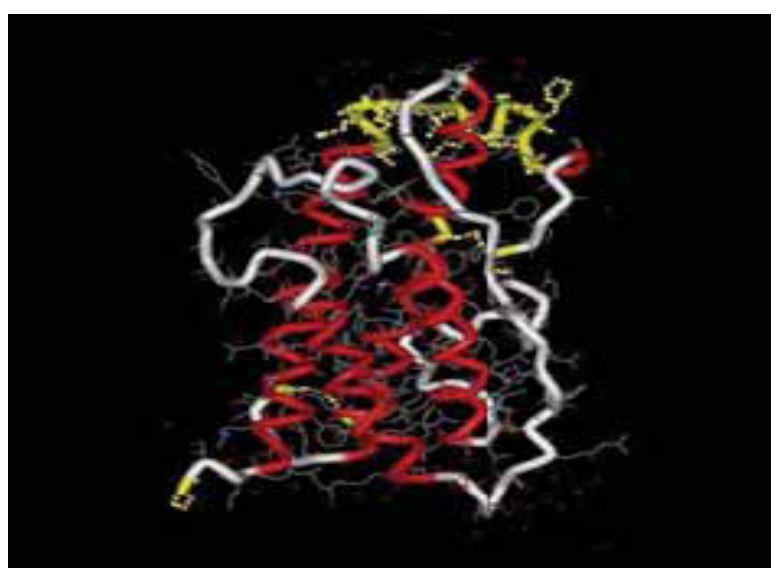

Figure 2: The growth hormone somatropin, in its correct 22-kD-hGH form. Three-dimensional structure, generated from the protein data base SWISS PROT. Structural data supplied with the help of the program RasMol. The $\mathrm{n}$-terminal amino acid (at the bottom left hand corner) is marked yellow, as are the disulphide bridges (and the sequence range missing on the $20 \mathrm{kDa} \mathrm{hGH}$

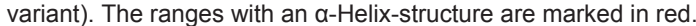

did it appear to improve athletic performance in females (mean age of 25 years) and males (mean age of 27 years) [34].

Administration of rhGH caused no further increase in muscle mass or strength, than that provided by resistance training in experienced male weight lifters (mean age of 22 years) attempting to further increase muscle mass [35].

Difficulties appear to have arisen in targeting an appropriate dose range that would promote muscle protein anabolism and not cause adverse effects, counteracting performance enhancement.

In contrast, a study was conducted on experienced male weight lifters, who were former AAS users (mean age of 31 years) that improved endurance performance, power and strength [36]. The beneficial effects were believed to have occurred because of AAS withdrawal inducing a state of catabolism, which was rectified by rhGH administration. Catabolism was identified by low results for insulin-like growth factor-1 (IGF-I) the surrogate marker of endogenous GH production [37]. Such research suggests that senescence or pharmaceutically induced catabolism are two conditions that may benefit from rhGH administration, in a sporting context.

\section{Detection of rhGH}

The current official method employed by WADA cannot detect pituitary hGH by blood or urine. Replacement GH is no longer derived from cadaver pituitaries, by pharmaceutical companies, because of the risk of Creutzfeldt-Jakob disease transmission. This is an incurable degenerative neurological disorder transmitted by contaminated harvested human brain products, which is invariably fatal. However unless an athlete can obtain purified cadaver pituitary, rhGH is the only form of the agent available.

$\mathrm{RhGH}$ is currently undetectable by urinalysis. Detection is by blood analysis and relies on the difference between the isoforms of hGH. Endogenous hGH comprises 70\%, 22 Kilodaltons (KDa) and $30 \%$, $20 \mathrm{KDa}$, whereas rhGH is $100 \% 22 \mathrm{KDa}$ [38]. RhGH induces the production of IGF-I and markers of collagen metabolism, type 3 procollagen (P-III-P), using mathematical equations which are different for males and females, but this has not yet been accepted by WADA
[39]. These GH-2000 formulae show reasonable sensitivity, with falsepositive rates of $\leq 1$ in 10,000 , but WADA will not adopt immunoassays they do not own, to prevent commercial companies changing their immunoassays. This is a political decision, not based on scientific discovery and is delaying a robust test which can withstand legal challenge.

A method of cycling the drug, one week on, one week off, using half strength doses can have significant effects on performance whilst thwarting the current detection techniques of the authorities [36].

Table 3 identifies genuine rhGH and Table 4 identifies potential counterfeit rhGH from internet companies.

\section{GHRelin (Growth Hormone Secretagogues)}

Growth hormone releasing hormone (GHRH) induces the synthesis and secretion of growth hormone, and somatostatin suppresses the secretion of growth hormone. Growth hormone is also regulated by ghrelin, a growth hormone secretagogue-receptor ligand that is synthesized mainly in the gastrointestinal tract [40]. Twice daily administration of ghrelin improved exercise capacity and left ventricular function in patients with chronic heart failure [41].

This knowledge has initiated the development of companies purporting to sell growth hormone secretagogues, such as sermorelin and its analogues (See Table 4).

\section{Insulin-like growth factor-1 (IGF-I)}

The insulin-like growth factors (IGFs) are proteins with high sequence similarity to insulin. They are part of a complex system that cells use to communicate with their environment. IGF-I is mainly secreted by the liver and is induced by GH secretion [37]. IGF-I induces cell proliferation and is thought to inhibit apoptosis [42] .

It consists of 70 amino acids in a single chain with three intramolecular disulfide bridges. IGF-I has a molecular weight of 7,649 daltons. It displays homology to proinsulin, the precursor of insulin [43].

IGF-I mediates some of the metabolic actions of GH and has both GH-like and insulin-like actions. Both GH and IGF-I have a net anabolic effect enhancing whole body protein synthesis, improving anthropometry in GHD. Both hormones have been used in catabolism and have been effective in counteracting the protein wasting effects of glucocorticoids. IGF-I administration improves insulin sensitivity, whereas GH therapy can cause compensatory hyperinsulinaemia.

Insulin-like growth factor-2 (IGF-2) is thought to be a primary growth factor required for early development while IGF-I expression is required for achieving maximal growth.

Factors that are known to cause variation in the levels of IGF-I in the circulation, include genetic make-up, diurnal variation, age, sex, exercise status, stress levels, nutrition and disease state.

IGF-I has an involvement in regulating neurogenesis, myelination, synaptogenesis, and dendritic branching and neuroprotection after neuronal damage. The IGF-I level reflects the secretory activity of $\mathrm{GH}$ and is a marker for identification of normal GH production [44]. Levels of IGF-I are at their peak during late adolescence and decline throughout adulthood, mirror imaging GH [45].

The stability of the IGF-I molecule, following administration by injection, has been enhanced by combining it with one of its binding proteins (BP). It is commercially available as rhIGFBP-3 which also limits adverse effects. 
Citation: Graham MR, Davies B, Grace FM, Evans PJ, Baker JS (2011) Exercise, Science and Designer Doping: Traditional and Emerging Trends. J Steroids Hormon Sci 2:109. doi:10.4172/2157-7536.1000109

No athlete has yet tested positive for rhIGF-I and published knowledge of its use in sport is limited. Tests for detecting it are currently being processed and consequently athletes have switched to doping with rhIGF-I as opposed to rhGH.

Its effect on physical exercise and anthropometry is being investigated, based on similar measurement of markers as rhGH action, with the hope of being available in time for the 2012 Olympics [46].

The concomitant administration of rhGH and rhIGF-I in GH resistant states has been shown to be synergistic and have effects that are far greater than either alone [44]. Athletes believe that the combination is more powerful than double of either alone and lower doses of either will limit detection (personal communications). Such beliefs appear to be supported by contemporary research $[39,44]$.

Table 3 identifies genuine rhIGF-I and Table 4 identifies potential counterfeit rhIGF-I from internet companies.

\section{Erythropoietin (Epo)}

Erythropoietin (Epo) is a glycoprotein hormone ( $40 \%$ carbohydrate) with a molecular weight of $32-39 \mathrm{KDa}$ that controls erythropoiesis, in the bone marrow. It is produced mainly by the peri-tubular capillary endothelial cells in the kidney but also in the liver.

Synthetic or pharmaceutical erythropoietins, Epoetins (Epos) or recombinant human erythropoietins (rhEpos), consist of epoetin alfa, beta, theta, and zeta. These erythropoiesis-stimulating agents (ESAs) are commercially available and are used to treat symptomatic anaemia associated with erythropoietin deficiency in chronic renal failure, to increase the yield of autologous blood in normal individuals and to shorten the period of symptomatic anaemia in patients receiving cytotoxic chemotherapy.

Darbepoetin is a hyperglycosylated derivative of epoetin; it has a longer half-life and can be administered less frequently than epoetin.

\begin{tabular}{|c|c|c|c|c|c|}
\hline \multicolumn{2}{|l|}{ Product } & \multicolumn{2}{|c|}{$\begin{array}{l}\text { Black-market } \\
\text { Pharmaceutical Manufacturer }\end{array}$} & $\begin{array}{l}\text { Black-market } \\
\text { Wholesale Price }\end{array}$ & $\begin{array}{l}\text { Black-market } \\
\text { Retail Price }\end{array}$ \\
\hline \multicolumn{6}{|l|}{ Peptide Hormones } \\
\hline \multicolumn{2}{|l|}{$\begin{array}{l}\text { Hygetropin } \\
\text { (rhGH) } \\
100 \mathrm{IU}\end{array}$} & \multicolumn{2}{|c|}{ Hygene Biopharm Co.,Ltd. } & $£ 100$ & $£ 140$ \\
\hline \multicolumn{2}{|l|}{$\begin{array}{l}\text { GenLei® Jintropin }{ }^{T M} \\
(\text { rhGH) } \\
100 \mathrm{IU}\end{array}$} & \multicolumn{2}{|c|}{ Gene Science Pharmaceutical Co., Ltd. } & $£ 100$ & $£ 140$ \\
\hline \multicolumn{2}{|l|}{$\begin{array}{l}\text { Turbovital } \\
\text { (rhlgf-1) } \\
1000 \text { mcg }\end{array}$} & \multicolumn{2}{|c|}{ Hygene Biopharm Co.,Ltd. } & $£ 200$ & $£ 285$ \\
\hline \multicolumn{6}{|l|}{ Growth Hormone Secretagogues } \\
\hline \multicolumn{2}{|l|}{$\begin{array}{l}\text { Hexarelin/Sermorelin/Ipamorelin } \\
\text { (growth hormone releasing hormone) } \\
\text { 2mg/amp }\end{array}$} & \multicolumn{2}{|c|}{ ProPeptides Co., Ltd } & $£ 24$ & $£ 50$ \\
\hline \multicolumn{6}{|l|}{ Myostatin inhibitor } \\
\hline \multicolumn{2}{|l|}{$\begin{array}{l}\text { Follistatin } 344 \\
(5 \mathrm{mcg})\end{array}$} & \multicolumn{2}{|c|}{ Southern Research Co., Ltd } & $£ 62$ & $£ 100$ \\
\hline Product & \multicolumn{3}{|c|}{ Pharmaceutical Manufacturer } & \multicolumn{2}{|l|}{ Mode of delivery } \\
\hline $\begin{array}{l}\text { Genotropin® } \\
\text { (somatropin/rhGH) } \\
\text { two-compartment cartridge containing } \\
\text { powder for reconstitution }\end{array}$ & \multicolumn{2}{|l|}{ Pharmacia } & $\begin{array}{l}\text { net price } \\
5.3-\mathrm{mg}(16 \text {-unit) cartridge }= \\
£ 122.87 ; \\
12-\mathrm{mg} \text { (36-unit) cartridge }= \\
£ 278.20\end{array}$ & \multicolumn{2}{|c|}{ Subcutaneous/Intramuscular } \\
\hline $\begin{array}{l}\text { Humatrope } ® \\
\text { (somatropin/rhGH) } \\
\text { two-compartment cartridge containing } \\
\text { powder for reconstitution }\end{array}$ & Lilly & & $\begin{array}{l}\text { net price } \\
6 \text {-mg (18-unit) cartridge }=£ 108.00 ; \\
24-m g(72 \text {-unit) cartridge }= \\
£ 432.00\end{array}$ & Subcutaneous/Intramı & \\
\hline $\begin{array}{l}\text { Norditropin }{ }^{\circledR} \\
\text { SimpleXx prefilled solution } \\
\text { (somatropin } 3.3 \mathrm{mg} ; 10 \text { units } / \mathrm{mL}\end{array}$ & Novo Nordisk & & $\begin{array}{l}\text { net price } \\
\text { 1.5-mL (5-mg, 15-unit) cartridge = } \\
£ 106.35 \text {; } \\
\text { 1.5-mL (15-mg, 45-unit) cartridge } \\
=£ 319.05\end{array}$ & Subcutaneous/Intramı & \\
\hline $\begin{array}{l}\text { Increlex® (Mecasermin } \\
10 \mathrm{mg} / \mathrm{mL} ; \\
\text { Recombinant human insulin-like growth } \\
\text { factor-1; rhIGF-1) }\end{array}$ & Ipsen & & $\begin{array}{l}\text { net price } \\
4-\mathrm{mL} \text { vial }=£ 605.00\end{array}$ & Subcutaneous/Intramı & \\
\hline $\begin{array}{l}\text { Eprex® } \\
\text { (prefilled syringe, epoetin alfa) } \\
\text { (Recombinant human erythropoietin; } \\
\text { rhEpo) }\end{array}$ & Janssen-Cilag & & $\begin{array}{l}\text { net price } \\
1000 \text { units }=£ 5.53 ; \\
40000 \text { units }=£ 265.48\end{array}$ & Subcutaneous/Intrave & \\
\hline $\begin{array}{l}\text { NeoRecormon® } \\
\text { (prefilled syringe, epoetin beta) } \\
\text { (Recombinant human erythropoietin; } \\
\text { rhEpo) }\end{array}$ & Roche & & $\begin{array}{l}\text { net price } \\
500 \text { units }=£ 3.75 ; \\
30000 \text { units }=£ 224.69\end{array}$ & Subcutaneous/Intrave & \\
\hline $\begin{array}{l}\text { Aranesp }{ }^{\circledR} \\
\text { Erythropoetin; } \\
\text { darbepoetin alfa, } 25 \text { micrograms } / \mathrm{mL}\end{array}$ & Amgen & & $\begin{array}{l}\text { net price } \\
0.4 \mathrm{~mL}(10 \text { micrograms })=£ 14.68, \\
1 \mathrm{~mL}(500 \text { micrograms })=£ 734.05\end{array}$ & Subcutaneous/Intrave & \\
\hline
\end{tabular}

Table 3: Prescription only Medicines, Peptide hormones used in hormone replacement. 
Methoxy polyethylene glycol-epoetin beta is a continuous erythropoietin receptor activator that is used for the treatment of symptomatic anaemia associated with chronic kidney disease. It has a longer duration of action than epoetin. The increase in red blood cell production is considered to be performance enhancing in endurance sports, such as middle or long distance running, cycling, skiing and swimming.

\section{Detection of rhEpo}

RhEpo was directly identified by urinalysis in 2000, when a test developed based on immunoelectrophoresis and double blotting (IEF/ $\mathrm{DB})$, was endorsed by the IOC and subsequently WADA [47]. It uses changes in the Epo isoform profile as detected by isoelectric focusing in polyacrylamide slab gels (IEF-PAGE).

The problem in detection has always been that the duration of the effect on performance is greater than the duration of any haematological changes associated with rhEpo use. Following discontinuation, red cell mass gradually returns to its original state but can take weeks, leaving an open window where there is no evidence of use but where performance is enhanced [48]

Testing for rhEpo in urine appears to be wrought with difficulties because the amount of endogenous Epo in urine, (urinary human epo, uhEpo) is extremely low [49]. The permeability of the renal tubules to Epo is complex. Exercise-induced renal ischaemia in conjunction with post-exercise proteinuria appears to affect the clearance of this peptide hormone. Also, by injecting microdoses of rhEpo, the window of detection can be reduced to as little as 12-18 hours post-injection [50].

Research on subjects who adminstered rhEpo for four weeks, with two weeks of "boosting", followed by two weeks of "maintenance" and a cessation period of three weeks, provided divisive results. A WADA "Laboratory $A$ " determined rhEpo use in all subjects during the boosting period, whereas WADA "Laboratory $B$ " found no use, with one sample to be negative, and the remaining seven to be suspicious. The detection rates decreased throughout the maintenance and post period when total haemoglobin mass and exercise performance were elevated. During this period, "Laboratory $A$ " found only two of 24 samples to be positive and three to be suspicious, and "Laboratory B" found no positive or suspicious samples. This study demonstrated a poor correlation in test results comparing two WADA-accredited laboratories. Consequently, after the initial rhEpo "boosting" period the power to detect rhEpo use during the maintenance and post periods appeared minimal [51]

The development of new ESAs, has required advanced methods for detecting the abuse of these substances. Blood markers became crucial, because synthetic Epos, harvested in animal cells, were best confirmed in serum after immunoaffinity purification. With the development of "Dynepo" (manufactured in cultured human, not animal cells), the additional application of sodium dodecylsulfatepolyacrylamide gel electrophoresis (SDS-PAGE) became necessary. The development of the haematological "athlete's biological passport" is the most recent advancement in indirect testing for ESA doping. Longitudinal monitoring of blood profiles by comparing athletes' individual hematological values against their own historical baselines rather than a population-derived threshold enhances the efficacy of indirect testing.

Recent developments in "dope testing" for Epo include molecular mass-based methods. The molecular mass of most rhEpos is higher than for uhEpo, which can be shown by SDS-PAGE [52].
Consequently from 2006, Epo tests at the Olympics have been conducted on both blood and urine, in an attempt to identify dopers, but the method officially adopted by WADA for the confirmation of rhEpo, is still urinalysis and still based on a combination of IEF/DB and distinguishes between endogenous erythropoietin and rhEpo isoforms.

Any false-positive Epo test concerns that researchers had up to this period [53] were contested and refuted relying on scientific analytical rigour [54].

\section{Does rhEpo enhance performance?}

RhEpo can be administered subcutaneously or intravenously and has performance-enhancing effects due to the powerful stimulation of red blood cell production, improving maximal oxygen uptake $(\dot{V}$ $\mathrm{O}_{2}$ max) thereby increasing delivery of oxygen to the exercising skeletal muscle.

It has been shown to increase maximal aerobic power [55] and $\dot{V} \mathrm{O}_{2} \max$ [48]. Cyclists have confessed to using it throughout their career demonstrating the difficulty in detecting it and their belief in its performance enhancement [56].

However, there are dangers to the exercising athlete using rhEpo. Arterial systolic blood pressure (SBP) at rest remains unaltered before and after rhEpo admin. During submaximal exercise at 200 watts, corresponding to an average of approx $50 \%$ of $\dot{V} \mathrm{O}_{2} \max$ SBP increases markedly from 177 to $191 \mathrm{mmHg}$, increasing stress on the heart during heavy strenuous and prolonged exercise [57]. During competition cycling and running, the average energy turn-over is often in the range of $75-85 \%$ of $\dot{V} \mathrm{O}_{2} \max$ for long periods.

Athletes who abuse recombinant human erythropoietin (rhEPO) only want to pass the finishing line in first place and have no consideration for any potential health consequences [58]. Exercise in healthy non-doped individuals, elevates packed cell volume and the dehydration associated with intense exercise can exacerbate blood viscosity which may expose previously undiagnosed cardiovascular abnormalities.

The use of rhEpo in chronic aerobic exercise, mimicking a sports doping model in rats, resulted in a sudden death episode during the eighth week, of a ten week trial [59]. The aetiology of death was suggested to be an elevation of packed cell volume, resulting in hyperviscosity, hypertension, cardiac hypertrophy, sympathetic and serotinergic overactivity. Post-mortem examination identified cerebral vascular congestion, left ventricular hypertrophy, and congestive hepatopathy caused by right-sided heart failure, which reinforced the hypothesis that there were several patho-physiological effects from rhEpo abuse.

Table 3 identifies genuine rhEpo and Table 4 identifies potential counterfeit rhEpo from an internet company.

\section{MGF (IGF-I Ec peptide)}

Muscle development must be under the control of local growth factors because if a specific muscle is mechanically overloaded, as in resistant exercise, it is that muscle and not all the muscles that undergo hypertrophy. Mechano growth factor (MGF) has been identified and appears to be derived from the IGF-I gene and has a unique C-terminal peptide (IGF-I Ec peptide). It has a molecular weight of 2868 daltons. After resistance exercise, which may cause disruption and damage to the myofibril cell membranes, the IGF-I gene predominantly produces the IGF-I splice variant IGF-I Ec peptide (MGF) which activates muscle stem (satellite) cells or muscle progenitor cells that provide the extra 
Citation: Graham MR, Davies B, Grace FM, Evans PJ, Baker JS (2011) Exercise, Science and Designer Doping: Traditional and Emerging Trends. J Steroids Hormon Sci 2:109. doi:10.4172/2157-7536.1000109

Page 8 of 10

\begin{tabular}{|c|c|c|c|}
\hline Product & $\begin{array}{l}\text { Black-market } \\
\text { Pharmaceutical Manufacturer }\end{array}$ & $\begin{array}{l}\text { Black-market } \\
\text { Wholesale Price }\end{array}$ & $\begin{array}{l}\text { Black-market } \\
\text { Retail Price }\end{array}$ \\
\hline \multicolumn{4}{|l|}{$\begin{array}{l}\text { Peptide Hormones } \\
\text { (Administration by Subcutaneous Injection) }\end{array}$} \\
\hline $\begin{array}{l}\text { Hygetropin } \\
(\text { rhGH) } \\
100 \mathrm{IU}\end{array}$ & Hygene Biopharm Co.,Ltd. & $£ 100$ & $£ 140$ \\
\hline $\begin{array}{l}\text { GenLei® Jintropin }{ }^{T M} \\
(\text { rhGH) } \\
100 \mathrm{IU}\end{array}$ & Gene Science Pharmaceutical Co., Ltd. & $£ 100$ & $£ 140$ \\
\hline $\begin{array}{l}\text { Turbovital } \\
\text { (rhlgf-1) } \\
1000 \mathrm{mcg}\end{array}$ & Hygene Biopharm Co.,Ltd. & $£ 200$ & $£ 285$ \\
\hline \multicolumn{4}{|l|}{ Growth Hormone Secretagogues } \\
\hline $\begin{array}{l}\text { Hexarelin/Sermorelin/lpamorelin } \\
\text { (growth hormone releasing hormones) } \\
\text { 2mg/amp }\end{array}$ & ProPeptides Co., Ltd & $£ 24$ & $£ 50$ \\
\hline Recombinant Human Erythropoietin-Alpha & Prospec Protein Specialist & $\begin{array}{l}5 \mu \mathrm{g} £ 32 ; 50 \mu \mathrm{g} £ 82 ; \\
1 \mathrm{mg} £ 940\end{array}$ & $\begin{array}{l}5 \mu \mathrm{g} £ 50 ; 50 \mu \mathrm{g} £ 100 ; 1 \mathrm{mg} \\
£ 1200\end{array}$ \\
\hline \multicolumn{4}{|l|}{ Myostatin inhibitor } \\
\hline $\begin{array}{l}\text { Follistatin } 344 \\
\text { (5 mcg/amp) }\end{array}$ & Southern Research Co., Ltd & $£ 62$ & $£ 100$ \\
\hline \multicolumn{4}{|l|}{ Mechano Growth Factor } \\
\hline $\begin{array}{l}\text { MGF (C-terminal) } \\
2 \mathrm{mg} \text { amp }\end{array}$ & Peptide Labs Research Peptides & $£ 18$ & $£ 50$ \\
\hline
\end{tabular}

Key: $a m p=$ ampoule; $r \mathrm{rGH}$ = recombinant human growth hormone; rhlgf-1 = recombinant human insulin-like growth factor-1

Table 4: Counterfeit Peptide Hormone Doping Agents.

nuclei required for muscle hypertrophy, repair and maintenance. The appearance of MGF also up-regulates new protein synthesis. After this initial splicing of IGF-I into MGF, production then switches towards producing a systemic release of IGF-I Ea from the liver, which also upregulates protein synthesis. The expression of IGF-I splice variants, over the course of the regeneration of muscle, following stress, is thought to be the primary anabolic mechanism by which the body repairs injuries or produces new muscle. Sarcopaenia and dystrophic muscle appear to have an impaired ability to express MGF or refresh the satellite cell pool [60].

Unlike mature IGF-I, the distinct E domain of MGF inhibits terminal differentiation whilst increasing myoblast proliferation. Blocking the IGF-I receptor with a specific antibody indicates that the function of MGF E domain is mediated via a different receptor, providing localised tissue adaptation and suggesting why loss of muscle mass occurs in the elderly and in dystrophic muscle in which MGF production is markedly affected [61]. Such potential has attracted the attention of commercial companies claiming to be able to manufacture such peptide hormones for athletic abuse. MGF is available commercially as an injectable peptide, and can be purchased from internet sites. It corresponds to the 24 most C-terminal residues of IGF-IEb, a different splice variant isoform of IGF-I and has anecdotally been shown to increase local muscle growth and cellular proliferation. However, no analogous peptide product of the IGF-I gene has been identified or isolated from cultured cells [62].

Research in humans, with MGF is currently under consideration.

Table 4 identifies a potential counterfeit MGF from an internet company.

\section{A Myostatin Inhibitor (Follistatin)}

Myostatin is a transforming growth factor- $\beta$ (TGF- $\beta$ ) family member that plays an essential role in regulating skeletal muscle growth. It acts as a negative regulator of skeletal muscle mass. Pharmacological agents capable of blocking myostatin activity may have applications for promoting muscle growth in human disease. Follistatin, also known as activin-binding protein is a peptide hormone, in humans, encoded by the FST gene. Follistatin is an autocrine glycoprotein that is expressed in nearly all tissues. It is part of the inhibin-activin-follistatin axis and is produced by folliculostellate (FS) cells of the anterior pituitary. In the tissues activin has a strong role in cellular proliferation, thereby making follistatin the safeguard against uncontrolled cellular proliferation and also allowing it to function as an instrument of cellular differentiation. Both of these roles are vital in tissue rebuilding and repair.

Follistatin has been assessed for its role in regulation of muscle growth in mice, as an antagonist to myostatin [63]. demonstrated that inhibition of myostatin, either by genetic elimination (knockout mice) or by increasing the amount of follistatin, resulted in greatly increased muscle mass. Mice that lack the gene that makes myostatin have roughly twice the amount of body muscle as normal. But mice without myostatin that also overproduce follistatin have about four times as much muscle as normal mice [64]. In 2009, research with Macaque monkeys demonstrated that regulating follistatin via gene therapy also resulted in muscle growth and increases in strength [65].

Such research paves the way for future control of disease states, but the application for the use of a myostatin inhibitor in sport is all too evident. There is currently no scientific proof that such a drug can benefit sport's performance in humans, however, multiple internet companies wax lyrical about the benefits of their products.

Table 4 identifies a potential counterfeit myostatin inhibitor (Follistatin 344) from an internet company.

\section{Conclusion}

The existence of high rewards from competitive sport will always predispose the more vulnerable athlete to experiment with the latest ergogenic aid or designer doping agent. 
Citation: Graham MR, Davies B, Grace FM, Evans PJ, Baker JS (2011) Exercise, Science and Designer Doping: Traditional and Emerging Trends. J Steroids Hormon Sci 2:109. doi:10.4172/2157-7536.1000109

The presence of the internet would appear to be an effective market-place for the acquisition of such products and to negate the requirement of a personal physician. However, there are few safeguards to confirm the veracity of these agents and to protect such individuals willing to risk life and limb, in pursuit of gold.

Despite the increased intensity in anti-doping, a level playing field even exists for the cheating dope! Following the "accidental" ingestion of a banned substance by the less discerning athlete, a sport scientist is often required as an expert, to contest any charge of wrong-doing by a prosecuting authority [66].

\section{References}

1. Waddington I (1996) The development of sports medicine. Sociology of Sport 13: $176-196$

2. Franke WW, Berendonk B (1997) Hormonal doping and androgeniization of athletes: a secret program of the German Democratic Republic Goverment. Clin Chem 43: 1262-1279.

3. Todd T (1987) Anabolic steroids: the gremlins of sport. J Sport Hist 14: 87-107.

4. Fair JD (1993) Isometrics or Steroids? Exploring New Frontiers of Strength in the Early 1960s. Journal of Sport History 20: 1-24.

5. http://sportsanddrugs. procon.org/view.resource.php?resourcelD=002366.

6. http://www.olympic.org/medical-commission.

7. Mottram DR (1999) Banned drugs in sport. Does the International Olympic Committee (IOC) list need updating? Sports Med 27: 1-10.

8. Donohoe T, Johnson N (1986) Foul play: Drug Abuse in Sports. Oxford: Blackwell Scientific Publications.

9. http://www.nytimes.com/keyword/ben-johnson.html

10. http://www.timesonline.co.uk/tol/sport/more_sport/athletics/article3942201.ece

11. http://news.bbc.co.uk/sport1/hi/olympics/athletics/7403158.stm

12. http://www.telegraph.co.uk/sport/othersports/drugsinsport/7293877.html

13. http://www.cyclingweekly.co.uk/news/latest/519647.html

14. http://www.perthnow.com.au/sport/marion-jones-letter-of-confession/storye6frg1wu-1111114586262; http://www.sportsscientists.com/2007/10/marionjones-self-confessed-drug-user.html

15. http://www.wada-ama.org/Documents/World_Anti-Doping_Program/WADPThe-Code/WADA_Anti-Doping_CODE_2009_EN.pdf.

16. Bamberger M, Yaeger D (1997) Over the edge. Sports Illustrated 14: 62-70.

17. Kicman AT, Gower DB (2003) Anabolic steroids in sport: biochemical, clinica and analytical perspectives. Ann Clin Biochem 40: 321-356.

18. Brooks RV, Firth RG, Sumner NA (1975) Detection of anabolic steroids by radioimmunoassay. Br J Sports Med 9: 89-92.

19. Ward RJ, Shackleton CH, Lawson AM (1975) Gas chromatographic mass spectrometric methods for the detection and identification of anabolic steroid drugs. Br J Sports Med 9: 93-97.

20. Oftebro H (1992) Evaluating an abnormal urinary steroid profile. Lancet 339 941-942.

21. Garle M, Ocka R, Palonek E, Björkhem I (1996) Increased urinary testosterone epitestosterone ratios found in Swedish athletes in connection with a national control program: evaluation of 28 cases. J Chromatogr B Biomed Appl 687: $55-59$.

22. Becchi M, Aguilera R, Farizon Y, Flament MM, Casabianca H, et al. (1994) Gas chromatography/combustion/isotope-ratio mass spectrometry analysis of urinary steroids to detect misuse of testosterone in sport. Rapid Commun Mass Spectrom 8: 304-308.

23. Bhasin S, Storer TW, Berman N, Callegari C, Clevenger B, et al. (1996) The effects of supraphysiologic doses of testosterone on muscle size and strength in normal men. N Engl J Med 335: 1-7.

24. http://www.wada-ama.org/en/Resources/Q-and-A/Lab-Statistics-Report/html.
25. Graham MR, Davies B, Grace FM, Kicman A, Baker JS (2008) Anabolic steroid use: patterns of use and detection of doping. Sports Med 38: 505-525.

26. http://www.premium-steroids.com/index.php?main_page=product info\&products_id=59.

27. Li CH, Evans HM (1944) The Isolation of Pituitary Growth Hormone. Science 99: 183-184.

28. Fryklund $L$ (1986) Current research on recombinant human growth hormone and the related growth factors, IGF-I and GRF. Acta Paediatr Scand Supp 325: 85-89.

29. Baumann G (1991) Growth hormone heterogeneity: genes, isohormones, variants, and binding proteins. Endocr Rev 12: 424-449.

30. Duchaine D (1982) Underground Steroid Handbook, $1^{\text {st }}$ ed. California: HLR Technical Books 84: 30.

31. Salomon F, Cuneo RC, Hesp R, Sönksen PH (1989) The effects of treatmen with recombinant human growth hormone on body composition and metabolism in adults with growth hormone deficiency. N Engl J Med 321: 1797-1803.

32. Rudman D, Feller AG, Nagraj HS, Gergans GA, Lalitha PY, et al. (1990) Effects of human growth hormone in men over 60 years old. N Engl J Med 323: 1-6.

33. Wallace JD, Cuneo RC, Baxter R, Orskov H, Keay N, et al. (1999) Responses of the growth hormone $(\mathrm{GH})$ and insulin-like growth factor axis to exercise, $\mathrm{GH}$ administration, and $\mathrm{GH}$ withdrawal in trained adult males: a potential test for GH abuse in sport. J Clin Endocrinol Metab 84: 3591-3601.

34. Berggren A, Ehrnborg C, Rosén T, Ellegård L, Bengtsson BA, et al. (2005) Short-term administration of supraphysiological recombinant human growth hormone $(\mathrm{GH})$ does not increase maximum endurance exercise capacity in healthy, active young men and women with normal $\mathrm{GH}$-insulin-like growth factor I axes. J Clin Endocrinol Metab 90: 3268-3273.

35. Yarasheski KE, Zachweija JJ, Angelopoulos TJ, Bier DM (1993) Short-term growth hormone treatment does not increase muscle protein synthesis in experienced weight lifters. J Appl Physiol 74: 3073-3076.

36. Graham MR, Baker JS, Evans P, Kicman A, Cowan D, Hullin D, et al. (2008) Physical effects of short term rhGH administration in abstinent steroid dependency. Hormone Research 69: 343-354.

37. Le Roith D, Scavo L, Butler A (2001) What is the role of circulating IGF-I? Trends Endocrinol Metab 12: 48-52.

38. Wu Z, Bidlingmaier M, Dall R, Strasburger CJ (1999) Detection of doping with human growth hormone. Lancet 353: 895

39. Powrie JK, Bassett EE, Rosen T, Jørgensen JO, Napoli R, et al. (2007) Detection of growth hormone abuse in sport. Growth Horm IGF Res 17: 220226.

40. Kojima M, Hosoda H, Date $\mathrm{Y}$, Nakazato M, Matsuo H, Kangawa K (1999) Ghrelin is a growth-hormone-releasing acylated peptide from stomach. Nature 9: 656-660.

41. Nagaya N, Moriya J, Yasumura Y, Uematsu M, Ono F, et al. (2004) Effects of ghrelin on left ventricular function, exercise capacity, muscle wasting in patients with chronic heart failure. Circulation 110: 3674-3679.

42. O'Reilly KE, Rojo F, She QB, Solit D, Mills GB, et al. (2006) mTOR inhibition induces upstream receptor tyrosine kinase signaling and activates Akt Cancer Res 66: 1500-1508.

43. Rinderknecht E, Humbel RE (1978) The amino acid sequence of human insulin-like growth factor I and its structural homology with proinsulin. J Biol Chem 253: 2769-2776

44. Mauras N, Haymond MW (2005) Are the metabolic effects of GH and IGFseparable. Growth Horm IGF Res 15: 19-27.

45. Milani D, Carmichael JD, Welkowitz J, Ferris S, Reitz RE, et al. (2004) Variability and reliability of single serum IGF-I measurements: impact on determining predictability of risk ratios in disease development. J Clin Endocrinol Metab 89: 2271-2274

46. Guha N, Sönksen PH, Holt RI (2009) IGF-I abuse in sport: current knowledge and future prospects for detection. Growth Horm IGF Res 19: 408-4011.

47. Lasne F, de Ceaurriz J (2000) Recombinant erythropoietin in urine. Nature 405: 635 .

48. Birkeland KI, Stray-Gundersen J, Hemmersbach P, Hallen J, Haug E, et al. 
Citation: Graham MR, Davies B, Grace FM, Evans PJ, Baker JS (2011) Exercise, Science and Designer Doping: Traditional and Emerging Trends. J Steroids Hormon Sci 2:109. doi:10.4172/2157-7536.1000109

Page 10 of 10

(2000) Effect of rhEPO administration on serum levels of STfR and cycling performance. Med Sci Sports Exerc 32: 1238-1243.

49. Delanghe JR, Joyner MJ (2008) Testing for recombinant human erythropoietin. J Appl Physiol 105: 395-396.

50. Ashenden M, Varlet-Marie E, Lasne F, Audran M (2006) The effects of microdose recombinant human erythropoietin regimens in athletes. Haematologica 91: 1143-1144.

51. Lundby C, Achman-Andersen NJ, Thomsen JJ, Norgaard AM, Robach P (2008) Testing for recombinant human erythropoietin in urine: problems associated with current anti-doping testing. J Appl Physiol 105: 417-419.

52. Reichel C (2011) Recent developments in doping testing for erythropoietin. Anal Bioanal Chem 401: 463-481.

53. Beullens M, Delanghe JR, Bollen M (2006) False-positive detection of recombinant human erythropoietin in urine following strenuous physical exercise. Blood 107: 4711-4713.

54. Catlin D, Green G, Sekera M, Scott P, Starcevic B (2006) False-positive Epo test concerns unfounded. Blood 108: 1779-17780.

55. Ekblom B, Berglund B (1991) Effect of rhEPO admin on maximal aerobic power in man. Medicine \& Science in Sports \& Exercise 1: 125-130.

56. http://news.bbc.co.uk/sport1/hi/other_sports/cycling/8694452.stm

57. Berglund B, Ekblom B (1991) Effect of rhEPO treatment on BP and haematological parameters in healthy males. Journal of Internal Medicine 229 $125-130$
58. Bamberger M, Yaeger D (1997) Over the edge. Sports Illustrated 14: 62-70.

59. Piloto N, Teixeira HM, Teixeira-Lemos E, Parada B, Garrido P, et al. (2009) Erythropoietin promotes deleterious cardiovascular effects and mortality risk in a rat model of chronic sports doping. Cardiovasc Toxicol 9: 201-210.

60. Goldspink G (2005) Research on mechano growth factor: its potential for optimising physical training as well as misuse in doping. Br J Sports Med 39 787-788.

61. Yang SY, Goldspink G (2002) Different roles of the IGF-I Ec peptide (MGF) and mature IGF-I in myoblast proliferation and differentiation. FEBS Lett 522 156-160.

62. Matheny RW, Nindl BC, Adamo ML (2010) Minireview: Mechano-growth factor: a putative product of IGF-I gene expression involved in tissue repair and regeneration. Endocrinology 151: 865-875.

63. Lee SJ, McPherron AC (2001) Regulation of myostatin activity and muscle growth. Proc Natl Acad Sci USA 98: 9306-9311.

64. 'Mighty mice' made mightier http://www.eurekalert.org/pub_releases/2007-08/ jhmi-mm082407.php.

65. "Success Boosting Monkey Muscle Could Help Humans" http://www.npr.org/ templates/story/story.php?storyld=120316010.

66. Graham MR, Ryan P, Davies B, Evans PJ, Baker JS (2009) Dope Opera! Is Nandrolone a Medicine or Doping Agent? Journal of Exercise Physiology 12 40-43. 